\title{
Dual Roles of Diadenosine Polyphosphates in Corneal Epithelial Cell Migration
}

\author{
Aránzazu Mediero, ${ }^{1}$ Assumpta Peral, ${ }^{2}$ and Jesús Pintor ${ }^{1}$
}

Purpose. To investigate the influence of diadenosine polyphosphates on the rate of corneal epithelial cell migration.

Methods. Primary corneal epithelial cell cultures were obtained from New Zealand White rabbits. Immunocytochemical experiments were performed by fixing the cells with $4 \%$ paraformaldehyde (PFA) and incubated with cytokeratin 3 primary antibody, which was subsequently incubated with a secondary IgG mouse labeled with FITC, and the cells were observed under confocal microscopy. Migration studies were performed by taking confluent monolayers that were wounded with a pipette tip and challenged with different di- and mononucleotides with or without P2 antagonist ( $n=8$ each treatment). For concentration-response analysis, compounds were tested in doses ranging from $10^{-8}$ to $10^{-3} \mathrm{M}(n=8)$. The stability of the dinucleotides was assayed by HPLC, with an isocratic method $(n=4)$.

REsults. Cells under study were verified as corneal epithelial cells via the immunocytochemical analysis. Cell migration experiments showed that $\mathrm{Ap}_{4} \mathrm{~A}$, UTP, and ATP accelerated the rate of healing $(5,2.75$, and 3 hours, respectively; $P<0.05$; $P<0.001)$, whereas $A p_{3} \mathrm{~A}, \mathrm{Ap}_{5} \mathrm{~A}$, and UDP delayed it $(6.5,10$, and 2 hours, respectively; $P<0.05$ ). ADP did not modify the rate of migration. Antagonists demonstrated that $\mathrm{Ap}_{4} \mathrm{~A}$ and $\mathrm{Ap}_{3} \mathrm{~A}$ did activate different $\mathrm{P} 2 \mathrm{Y}$ receptors mediating corneal wound-healing acceleration and delay. Concerning the possible degradation of the dinucleotides, it was almost impossible to detect any products resulting from their cleavage.

Conclusions. Based on the pharmacological profile of all the compounds tested, the two main $\mathrm{P} 2 \mathrm{Y}$ receptors that exist in these corneal cells are a $\mathrm{P} 2 \mathrm{Y}_{2}$ receptor accelerating the rate of healing and $\mathrm{P} 2 \mathrm{Y}_{6}$ receptor that delays this process. (Invest Ophthalmol Vis Sci. 2006;47:4500-4506) DOI:10.1167/ iovs.06-0209

$\mathrm{T}$ here are certain physiological processes that are naturally modified by the action of extracellular nucleotides, such as ATP or UTP. ${ }^{1}$ These nucleotides alter the functioning of cells and tissues because they can bind to membrane receptors termed P2 purinoceptors. ${ }^{2}$ Two main families of $\mathrm{P} 2$ receptors have been studied: metabotropic P2Y and ionotropic P2X receptors. $\mathrm{P} 2 \mathrm{Y}$ receptors are seven transmembrane domain proteins coupled to $G$ proteins that trigger different signaltransduction mechanisms. Eight different proteins have been

From the ${ }^{1}$ Departamento de Bioquímica y Biología Molecular IV and the ${ }^{2}$ Departamento de Óptica II, E. U. Óptica, Universidad Complutense de Madrid, Madrid, Spain. Madrid.

AM holds a fellowship from the Universidad Complutense de

Submitted for publication February 27, 2006; revised May 16 and June 12, 2006; accepted August 9, 2006.

Disclosure: A. Mediero, None; A. Peral, None; J. Pintor, None

The publication costs of this article were defrayed in part by page charge payment. This article must therefore be marked "advertisement" in accordance with 18 U.S.C. $\$ 1734$ solely to indicate this fact.

Corresponding author Jesús Pintor, Dept. Bioquímica y Biología Molecular IV, E.U. Óptica, Universidad Complutense de Madrid, c/Arcos de Jalón s/n, 28037 Madrid, Spain; jpintor@vet.ucm.es. cloned so far: $\mathrm{P}_{1}, \mathrm{Y}_{1} \mathrm{Y}_{2}, \mathrm{P}_{4} \mathrm{Y}_{4}, \mathrm{P} \mathrm{Y}_{6}, \mathrm{P} \mathrm{Y}_{11}, \mathrm{P} 2 \mathrm{Y}_{12}, \mathrm{P} 2 \mathrm{Y}_{13}$, and $\mathrm{P}_{2} \mathrm{Y}_{14}{ }^{3}$. Although in general all the receptors are widely distributed, the last four are particularly important in processes such as the maintenance of the vascular tone and platelet aggregation. ${ }^{4,5}$

On the other hand, P2X ionotropic receptors are formed by two or three different subunits to construct an active receptor. ${ }^{6}$ It seems that in native tissues $\mathrm{P} 2 \mathrm{X}$ receptors are formed by a heteromeric combination of subunits rather than a homomeric one. ${ }^{7} \mathrm{P} 2 \mathrm{X}$ receptors are involved in processes in which cells are excited by the action of nucleotides, a mechanism that is extraordinarily important in excitable cells such as neurons. ${ }^{8}$

The eye presents both types of $\mathrm{P} 2$ receptors in most of its structures.9 Although in some cases it is not clear which P2 receptor subtype is activated by the nucleotides, the use of cell cultures obtained from different areas in combination with the development of $\mathrm{P} 2$ receptor antibodies provides an accurate picture of the different nucleotide receptors present in the eye. In eye sections, by using $\mathrm{P} 2 \mathrm{Y}$ receptor antibodies, it has been possible to see the existence of those receptors in the cornea, iris, ciliary processes, and retina, among other areas. ${ }^{10}$

It is generally accepted that the main naturally active nucleotide is ATP, but over the past 20 years, a new group of extracellular nucleotides, the dinucleoside polyphosphates, have received a great deal of attention. ${ }^{11}$ Constituted by two nucleosides linked by a variable number of phosphates (from two to seven) and mostly formed with two adenosine moieties (diadenosine polyphosphates), they can activate $\mathrm{P} 2$ nucleotide receptors as well as their own dinucleotide receptors. ${ }^{12}$ Diadenosine polyphosphates have been described in tears and in the aqueous humor, together with other adenine mononucleotides. In this sense, and acting within the eye, it has been possible to demonstrate the action of diadenosine polyphosphates regulating IOP. This effect seems to occur in the trabecular meshwork cells where $\mathrm{P}_{2} \mathrm{Y}_{1}$ receptors reduce IOP when eyes are challenged with diadenosine tetraphosphate $\left(\mathrm{Ap}_{4} \mathrm{~A}\right){ }^{13}$

On the ocular surface the presence of diadenosine polyphosphates, mainly diadenosine triphosphate, $A_{p_{3}} \mathrm{~A}$; diadenosine tetraphosphate, $\mathrm{Ap}_{4} \mathrm{~A}$; and diadenosine pentaphosphate, $\mathrm{Ap}_{5} \mathrm{~A}$, have been described. ${ }^{14,15}$ These compounds are able to increase tear production in rabbits by a mechanism in which P2Y receptors are involved. More recently, $A p_{4} A$ and UTP have been observed as active substances facilitating the rate of corneal re-epithelialization in New Zealand White rabbits. ${ }^{16}$ Although the results are clear, the limitation of the animal model does not allow full investigation of the role of diadenosine polyphosphates on corneal wound healing. For this reason, in the present experimental work, we have optimized a primary corneal epithelial cell culture, and we have investigated the role of diadenosine polyphosphates on corneal cell migration.

\section{Methods}

\section{Cell Culture}

All animals were treated in accordance with the ARVO Statement for the Use of Animals in Ophthalmic and Vision Research and experi- 
ments were performed in accordance with the European Communities Council Directive (89/609/EEC). Primary corneal epithelial cells were obtained from healthy eyes from adult New Zealand White rabbits euthanatized with pentothal sodium. Cell culture was performed according to the protocol described by Gipson and Grill, ${ }^{17}$ with some minor modifications. Briefly, eyes were enucleated, and the globes were placed in Hanks' balanced salt solution (HBSS) while corneal dissection under a dissecting microscope was performed. The cornea was removed along the limbus and cut into pieces. Incubation of the corneas in 1.0 U Dispase II (Roche Molecular Biochemicals, Indianapolis, IN) was performed for 1 hour at $37^{\circ} \mathrm{C}$ in $5 \% \mathrm{CO}_{2}$ and $95 \%$ humidity. The epithelium was peeled from the stroma and placed in $0.05 \%$ trypsin $0.5 \mathrm{M}$ EDTA for 20 minutes at $37^{\circ} \mathrm{C}$. The epithelium was collected in a tube containing $10 \mathrm{~mL}$ Dulbecco's modified medium (DMEM; Invitrogen, Paisley, UK) supplemented with 10\% FBS and 1\% penicillin-streptomycin (both from Invitrogen), and centrifuged twice at $1100 \mathrm{rpm}$ for 6 minutes at $4^{\circ} \mathrm{C}$. Finally, cells were resuspended in DMEM supplemented with $10 \%$ FBS and $1 \%$ penicillin-streptomycin and cultured in six multiwell plates until confluence. Cells were kept in a $\mathrm{CO}_{2}$ incubator at $37^{\circ} \mathrm{C}, 5 \% \mathrm{CO}_{2}$, and $95 \%$ humidity until confluence.

\section{Immunocytochemistry for Cytokeratin 3}

Corneal epithelial cells were grown to $80 \%$ confluence on coverslips After three washes with $10 \times$ phosphate-buffered saline (PBS), the cells were fixed for 15 minutes at room temperature with $4 \%$ paraformaldehyde in 0.15 M PBS. Washed again with PBS $10 \times$, the cells were permeabilized with blocking solution (PBS $1 \times$ BSA 3\% Triton X-100 FBS $5 \%$ ) for 1 hour at $37^{\circ} \mathrm{C}$, to block the nonspecific binding sites. Cells were then washed with PBS $1 \times$ BSA $3 \%$ and incubated with primary mouse monoclonal anti-cytokeratin 3 (1:100, Biogenesis, Düsseldorf, Germany) or PBS $1 \times$ BSA $3 \%$ for negative controls overnight at $4{ }^{\circ} \mathrm{C}$. Cells were washed twice in PBS $1 \times$ BSA $3 \%$ and incubated with the secondary antibody goat anti IgG mouse FITC (1:200; Sigma-Aldrich, St. Louis, MO) for 1 hour at $37^{\circ} \mathrm{C}$. Finally, coverslips were applied to the slides with mounting medium (Invitrogen). The cells were observed by confocal microscope (Axiovert 200M; Carl Zeiss Meditec GmbH, Jena, Germany), equipped with a Pascal confocal module (LSM 5; Zeiss). All images were managed with the accompanying Pascal software.

\section{Migration Assays}

To study the effect of dinucleoside polyphosphates and mononucleotides on corneal epithelial migration (as occurs in vivo in wound healing), experiments were performed on confluent monolayers on 24-well plates. Confluent monolayers were wounded by scraping the cell monolayer with a pipette tip, with just one touch of the monolayer and without any further movement. ${ }^{18,19}$ The initial wound size and shape were comparable $\left(60,000-80,000 \mu \mathrm{m}^{2}\right)$, to account for the variations in wound closure due to size, so that healing showed the same mechanistic features as previously indicated by other investigators. ${ }^{20}$ Wound area measurements (for each treatment) were collected from eight different wells and averaged as one measurement (mean \pm SEM). These eight experiments were performed in four independent primary rabbit corneal epithelial cell cultures.

Dinucleoside polyphosphates $\left(\mathrm{Ap}_{3} \mathrm{~A}, \mathrm{Ap}_{4} \mathrm{~A}, \mathrm{Ap}_{5} \mathrm{~A}\right)$ and nucleotides (ATP, UTP, ADP, UDP) were assayed across a wide range of doses, from $0.01 \mu \mathrm{M}$ to $1 \mathrm{mM}$, to obtain the corresponding concentration-response curves. Some wounds were used as the control (treated with Locke medium), and others were treated with dinucleotides and nucleotides ( $n=8$ each). After the culture medium was removed, cells were challenged for 2 minutes with the dinucleotide or nucleotide in Locke medium, to avoid interference, as previously reported for media such as DMEM. ${ }^{21}$ After this incubation, cells were washed, and fresh DMEM was added. The nucleotide dose was added to the wound at time 0 and every 6 hours, as previously described for rabbits. ${ }^{16}$ Images were captured every 2 hours during the first 10 hours and at 24 hours after the beginning of the experiment. Wounds were measured using the confocal microscope (LSM 5 Pascal software and Axiovert 200 M; Carl Zeiss Meditec, GmbH).

To compare the effect of the tested compounds in wound healing, we assayed them at a single dose of $100 \mu \mathrm{M}$, where the eight compounds reached their maximum effect. To perform these experiments we followed the same protocol as that described for concentrationresponse curve assays ( $n=8$ each).

P2 receptor antagonists such as pyridoxalphosphate-6-azophenyl2'4'disulfonic acid (PPADS), suramin (both from Tocris, Bristol, UK) and reactive blue 2 (RB2; Sigma-Aldrich) were initially assayed at 100 $\mu \mathrm{M}$ in the presence and absence of the agonist $\left(\mathrm{Ap}_{3} \mathrm{~A}\right.$ or $\mathrm{Ap}_{4} \mathrm{~A}, 100 \mu \mathrm{M}$ each). Antagonist $(100 \mu \mathrm{M})$ in Locke medium was exposed to wounded cells 30 minutes before the application of $100 \mu \mathrm{M} \mathrm{Ap} \mathrm{A}_{3} \mathrm{~A}$ or $\mathrm{Ap}_{4} \mathrm{~A}$ (together with the antagonist) in Locke medium, by using the same procedure as described earlier $(n=8)$.

Graded doses of suramin or RB2 ranging from $0.1 \mu \mathrm{M}$ to $1 \mathrm{mM}$ were assayed to obtain concentration-response curves in the presence of $\mathrm{Ap}_{4} \mathrm{~A} 100 \mu \mathrm{M}$ (for Suramin) or $\mathrm{Ap}_{3} \mathrm{~A} 100 \mu \mathrm{M}$ (for RB2; $n=8$ each).

\section{Analysis of Data}

To model the nonlinear decrease in wound area during epithelial healing, the constant-velocity method previously described ${ }^{20}$ was used with some modifications. Briefly, migration rates were determined by linear regression of the decrease in wound area during 10 hours of measurements and were obtained by the slope of the regression line, expressed as $\Delta$ area decrease per hour. The total time of wound closure was calculated by extrapolation of the best fit of the regression line during the healing phase to $100 \%$ closure of each wound tested.

Migration rates, expressed as estimated migration rates (EMR) and the estimated time for wound closure, presented as estimated healing time (EHT) in treated and control wounds were compared using one-way ANOVA. Average values were expressed as mean \pm SEM. The levels of significance for the differences are indicated in each case in the figure legends.

When we represent the linear regression of the decrease in wound area, data are expressed as a percentage of the time- 0 wound width, to normalize variability in wounding from well to well and experiment to experiment, according to a strategy described by others. ${ }^{19,22}$ EMR variations are expressed as $\%$ area decrease $\times$ hours $^{-1}$, and all data are related to the control to minimize the intrinsic levels in the medium.

\section{Analysis of the Dinucleotides by HPLC}

Determination and quantification of the diadenosine polyphosphate's stability after the assays were performed by HPLC. The chromatographic system consisted of an isocratic HPLC pump (1515; Waters, Milford, MA), a dual-absorbance detector (2487; Waters), and an injector (Reodyne, Rohnert Park, CA), all managed by HPLC system software (Breeze; Waters). The column was a C18 $(15 \mathrm{~cm}$ length, $0.4 \mathrm{~cm}$ diameter; Novapack) from Waters.

The system was equilibrated overnight with the following mobile phase: $0.1 \mathrm{M} \mathrm{KH}_{2} \mathrm{PO}_{4}, 2 \mathrm{mM}$ tetrabutyl ammonium, $17 \%$ acetonitrile (pH 7.5). Dinucleotides were detected at 260-nm wavelength. Peaks were transformed into concentrations by means of external standards of known concentrations of diadenosine polyphosphates.

\section{Results}

\section{Immunocytochemistry for Cytokeratin 3}

To verify that the isolated cells were corneal epithelial cells, an immunocytochemical analysis with cytokeratin 3 was performed. This protein is a component of intermediate filaments in epithelial cells and is a specific marker for corneal epithelial cells. $^{23}$ Corneal epithelial cells in culture depict a polygonal morphology when observed under Nomarsky optics. Combined with the specific marker cytokeratin 3, it was possible to confirm that all the cells obtained after the primary culture 
were positive for this protein (data not shown). Labeling was present across the whole cytoplasm, according to the position of intermediate filaments in the cell. Thus, we can conclude that the isolated cells were corneal epithelial cells, and so we investigated the role of extracellular dinucleotides in these cells

\section{Concentration-Response Curves for the Effects of Di- and Mononucleotides on Migration Rate}

To know whether dinucleoside polyphosphates $\left(\mathrm{Ap}_{3} \mathrm{~A}, \mathrm{Ap}_{4} \mathrm{~A}\right.$, and $A p_{5} A$ ) and mononucleotides (ATP, UTP, ADP, and UDP) could change the cell migration rate, we assayed them over a wide range of concentrations $(0.01 \mu \mathrm{M}$ to $1 \mathrm{mM})$, to generate concentration-response curves.

When the seven compounds were tested, three different effects on the rate of migration and healing time were found Some of the tested dinucleotides and nucleotides $\left(\mathrm{Ap}_{4} \mathrm{~A}, \mathrm{ATP}\right.$ and UTP) increased the wound-healing rate, others $\left(A p_{3} A\right.$, $\mathrm{Ap}_{5} \mathrm{~A}$, and UDP) reduced cell migration, and ADP did not alter cell migration when compared with the controls (data not shown).

In Figure 1A the EMR concentration-response curves for those compounds increasing cell migration- $\mathrm{Ap}_{4} \mathrm{~A}, \mathrm{ATP}$, and $\mathrm{UTP}-$ is presented. Graded doses of both $\mathrm{Ap}_{4} \mathrm{~A}$ and UTP elicited a sigmoid response pattern that had a $\mathrm{pD}_{2}$ value of $6.05 \pm$ 0.49 and $5.97 \pm 0.6$, respectively $\left(\mathrm{EC}_{50}\right.$ of $0.89 \mu \mathrm{M}$ for $\mathrm{Ap}_{4} \mathrm{~A}$ and $1.07 \mu \mathrm{M}$ for UTP). Unexpectedly, when the concentration-response curve for ATP was studied, it was found that this mononucleotide followed a bell-shaped curve (Fig. 1A). Exposure to low agonist concentrations $(1 \mu \mathrm{M})$ was associated with the highest mobility ( $\mathrm{pD}_{2}$ of 6 ), whereas higher concentrations $(10 \mu \mathrm{M}$ and $1 \mathrm{mM})$ failed to induce cell migration. It was only the single dose of $1 \mu \mathrm{M}$ that had an effect in increasing wound healing.

When the same experiments were performed for those compounds reducing the rate of migration $\left(A p_{3} A, A p_{5} A\right.$, and UDP), it was possible to observe sigmoid concentration-response curves. The $\mathrm{pD}_{2}$ obtained was $5.29 \pm 1.5$ for $\mathrm{Ap}_{3} \mathrm{~A}$, $5.759 \pm 0.09$ for $A_{5} A$, and $5.62 \pm 0.97$ for UDP, resulting in an $\mathrm{EC}_{50}$ of $5.13,1.73$, and $2.39 \mu \mathrm{M}$, respectively (Fig. 1B).

Based on the concentration-response curves, it was possible to display a rank order of potency for those compounds increasing the rate of migration, which was $\mathrm{Ap}_{4} \mathrm{~A}>\mathrm{UTP}>$ ATP. In the same way, the order of potency of those compounds that reduce the rate of healing was $A p_{5} A>A p_{3} A \cong$ UDP. These pharmacology profiles suggest the existence of two purinergic receptors: a $\mathrm{P} 2 \mathrm{Y}_{2}$-involved cell migration and a $\mathrm{P} \mathrm{Y}_{6}$-decreasing cell migration.

Since one of the most relevant features of the tested nucleotides is their ability to accelerate or delay wound healing, we compared the ability of all by assaying them at the concentration that produced the maximum effect $(100 \mu \mathrm{M})$.

In Figure 2A, a series of micrographs, in which we can compare the migration process after treatment with $A p_{4} A(100$ $\mu \mathrm{M})$ compared with the control, is presented. As is shown, after the challenge with $\mathrm{Ap}_{4} \mathrm{~A} 100 \mu \mathrm{M}$, the migration rate increased, and the time necessary to close the wound was significantly reduced. This can also be observed in Figure 2B, where a plot for $\mathrm{Ap}_{4} \mathrm{~A} 100 \mu \mathrm{M}$ showing variation of the wounded area versus time is presented. $\mathrm{Ap}_{4} \mathrm{~A}$ significantly increased the EMR relative to control, accompanied with a decrease in EHT.

In Table 1, the results for the whole series of tested compounds (all at $100 \mu \mathrm{M}$ ) in terms of EMR and EHT are presented. Among the tested compounds, $\mathrm{Ap}_{4} \mathrm{~A}$ showed an increase in EMR with a decrease in EHT $(P<0.001)$. The same behavior occurred with ATP and UTP $(P<0.05)$, which also increased
A

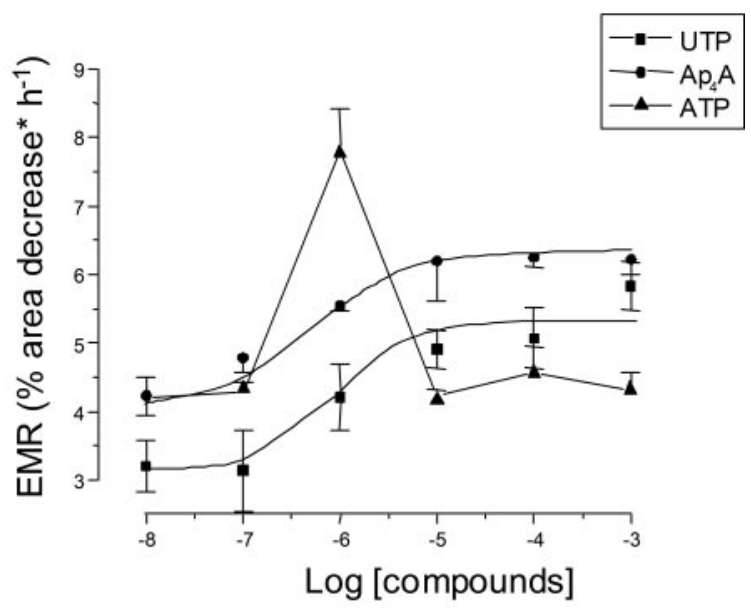

B

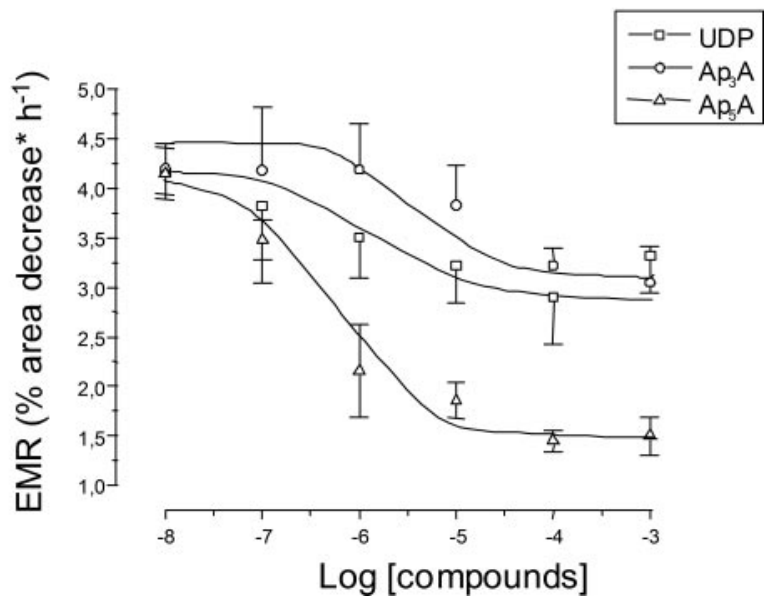

FIGURE 1. Concentration-response curves for di- and mononucleotides on the rate of migration. (A) The concentration-response curves for the three compounds that increased migration rate $\left(\operatorname{Ap}_{4} \mathrm{~A}, \mathrm{ATP}\right.$, and UTP). Ap 4 A and UTP follow a sigmoid response pattern, whereas ATP follows a bell-shaped curve. (B) Concentration-response curves for the compounds delaying the rate of migration $\left(\mathrm{Ap}_{3} \mathrm{~A}, \mathrm{Ap}_{5} \mathrm{~A}\right.$, and UDP).

EMR and reduced EHT. In contrast, the EMR for $A p_{3} A$ was reduced, whereas the EHT was increased. The same behavior was obtained with $\mathrm{Ap}_{5} \mathrm{~A}(P<0.05)$. Finally, ADP presented an EMR and EHT similar to the control values.

\section{Studies with P2 Receptor Antagonists}

To understand fully the receptors involved in the two processes described in the present manuscript, the $\mathrm{P} 2$ antagonists suramin, PPADS, and RB2 were assayed at a single dose of 100 $\mu \mathrm{M}$ in the presence of $\mathrm{Ap}_{4} \mathrm{~A}$ and $\mathrm{Ap}_{3} \mathrm{~A}$ (both at $100 \mu \mathrm{M}$ ). Wounded cells were preincubated for 30 minutes in the presence of the indicated antagonist and then were incubated for 2 minutes with the corresponding agonist.

As shown in Table 2, the application of a single dose of 100 $\mu \mathrm{M}$ of suramin, PPADS, or RB2 significantly reversed the effect of $A p_{4} A$, because the EMR was reduced while the EHT was concomitantly increased. For the effect of $\mathrm{Ap}_{4} \mathrm{~A}$, the most effective antagonist reducing the rate of healing was suramin $(P<0.05)$.

When the antagonists were tested with $\mathrm{Ap}_{3} \mathrm{~A}$, suramin did not revert the delayed effect in the rate of healing triggered by 
A

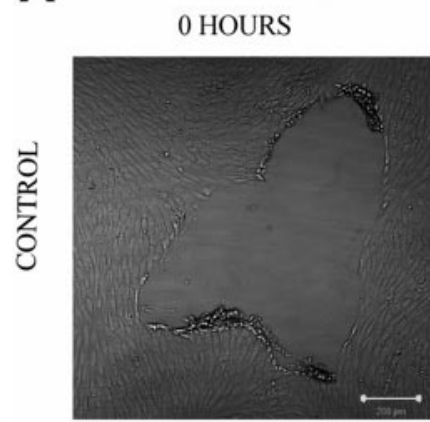

6 HOURS
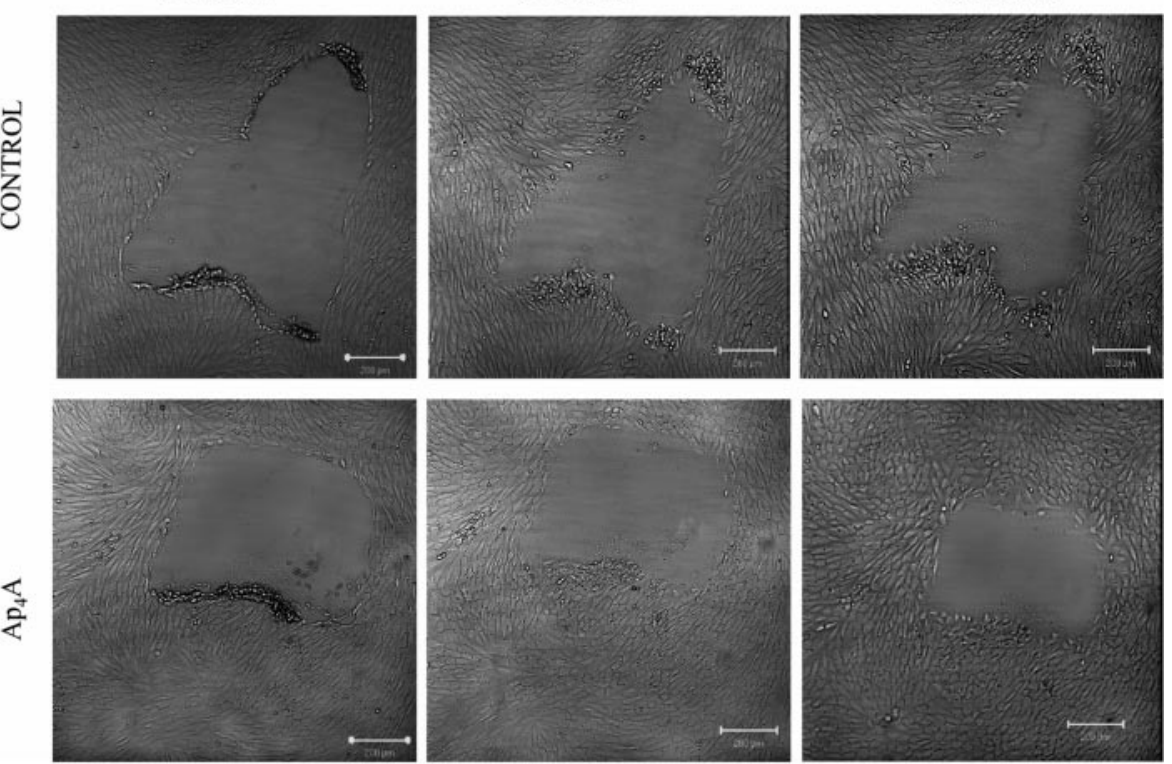

Figure 2. Effects of $\mathrm{Ap}_{4} \mathrm{~A}$ on corneal epithelial cell migration. (A) Shows a series of pictures to compare the migration process in control conditions and after $100 \mu \mathrm{M} \mathrm{Ap}{ }_{4} \mathrm{~A}$, on cultured cell monolayers. The micrographs were obtained at 0,6 , and 10 hours in the absence (control) and in the presence of $\mathrm{Ap}_{4} \mathrm{~A} 100 \mu \mathrm{M}$. (B) Plot representing the variation of the wounded area versus time. $A_{4} A$ $100 \mu \mathrm{M}$ increased EMR and reduced EHT when compared with the control.

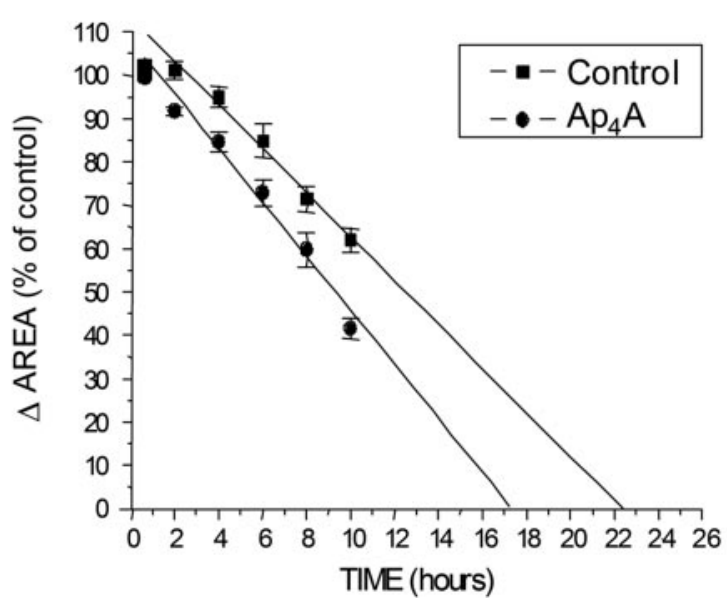

may favor the action of $\mathrm{Ap}_{3} \mathrm{~A}$ over the receptor that inhibits the cell migration rate $(P<0.05)$.

The ability of suramin to antagonize the effect of $\mathrm{Ap}_{4} \mathrm{~A}$ was tested at a wide range of concentrations of the antagonist. Figure $3 \mathrm{~A}$ shows that graded concentrations of suramin decreased the ability of $\mathrm{Ap}_{4} \mathrm{~A}$ to accelerate the rate of healing. The $\mathrm{pA}_{2}$ for suramin was $5.17 \pm 0.59\left(\mathrm{IC}_{50}\right.$ of $\left.6.76 \mu \mathrm{M}\right)$. When the same experiment was performed with $\mathrm{Ap}_{3} \mathrm{~A}$ and RB2 (Fig.

TABLE 2. EMR and EHT for Ap4A and Ap4A in the Presence of P2 Receptor Antagonists

\begin{tabular}{lcr}
\hline $\begin{array}{c}\text { Compound } \\
(\mathbf{1 0 0} \boldsymbol{\mu M})\end{array}$ & $\begin{array}{c}\text { EMR } \\
(\%)\end{array}$ & $\begin{array}{c}\Delta \text { EHT } \\
(\mathbf{h})\end{array}$ \\
\hline Control & $4.20 \pm 0.15$ & 0 \\
Ap4A & $6.25 \pm 0.33^{* * *}$ & -5 \\
Suramin + Ap4A & $3.06 \pm 0.34^{*}$ & +11 \\
PPADS + Ap4A & $3.75 \pm 0.19$ & +6 \\
RB2 + Ap4A & $3.63 \pm 0.33$ & +7 \\
\hline
\end{tabular}

Data are as described in Table 1.

${ }^{*} P<0.05, \quad{ }^{* * *} P<0.001$ versus control 
TABle 3. EMR and EHT for Ap3A and Ap3A in the Presence of the P2 Receptor Antagonist

\begin{tabular}{lcc}
\hline $\begin{array}{c}\text { Compound } \\
(\mathbf{1 0 0} \boldsymbol{\mu M})\end{array}$ & $\begin{array}{c}\text { EMR } \\
(\%)\end{array}$ & $\begin{array}{c}\Delta \mathbf{E H T} \\
(\mathbf{h})\end{array}$ \\
\hline Control & $4.20 \pm 0.15$ & 0 \\
Ap3A & $3.83 \pm 0.18$ & +6.5 \\
Suramin + Ap3A & $3.92 \pm 0.39$ & +6 \\
PPADS + Ap3A & $3.33 \pm 0.38$ & +10.5 \\
RB2 + Ap3A & $3.06 \pm 0.38^{*}$ & +12.5 \\
\hline
\end{tabular}

Data are as described in Table 1.

${ }^{*} P<0.05$ versus control.

$3 \mathrm{~B})$, the antagonist presented a $\mathrm{pA}_{2}$ of $3.48 \pm 0.30\left(\mathrm{IC}_{50}\right.$ of $331.13 \mu \mathrm{M})$.

When the three antagonists were assayed in the absence of any agonist, all reduced the rate of re-epithelialization, the best being PPADS (results not shown). This effect indicates the presence of extracellular nucleotides in the medium and that these nucleotides may activate preferentially the receptor that accelerates re-epithelialization $\left(\mathrm{P}_{2} \mathrm{Y}_{2}\right)$. A possible explanation of this may be the presence of nucleotides at the extracellular medium as a consequence of the mechanical stress. Lazarowski et al. $^{24}$ have demonstrated that, even in the most controlled conditions, epithelial cells can release nucleotides when, for example, cells are simply superfused with buffer. It could be the case that minor but slightly effective extracellular concentrations of nucleotides may be present after the application of the different agonists and antagonists. This "background" nucleotide concentration would be specially detected when antagonists are present in the medium.

\section{Stability of Diadenosine Polyphosphates}

Dinucleotides can be cleaved by the action of ectoenzymes which transform these molecules into mononucleotides. It could be the case that the effects reported herein are due to the degradation products of the dinucleotides rather than to their own effects. To prove this, both $A p_{4} A$ and $A p_{3} A$ were assayed under the conditions described in the Methods section.

Concerning the extracellular behavior of $\operatorname{Ap}_{4} \mathrm{~A}$, we did not observe any product derived from its hydrolysis after 2 minutes of incubation (Figs. 4A, 4C). Even in the presence of the antagonist suramin (which has been reported to block some ectonucleotidases), it was not possible to see any difference at all.

When $\mathrm{Ap}_{3} \mathrm{~A}$ was used instead, no hydrolysis was observed after 2 minutes (Figs. 4B, 4C). Also, in the presence of the antagonist RB-2, the lack of hydrolysis was observed.

\section{Discussion}

Diadenosine polyphosphates are active molecules present in tears that can exert several effects on corneal epithelium. When applied on corneal epithelial cells in culture, diadenosine polyphosphates elicit different effects, depending on the phosphate chain bridging between the two adenosines. $A p_{4} A$ accelerated the rate of re-epithelialization whereas $A p_{3} A$ or $A p_{5} \mathrm{~A}$ did the opposite, delaying the wound-healing process. Other nucleotides, such as ADP did not modify the rate of healing when compared with the control. In both cases, a positive or negative effect on re-epithelialization, the effects may be justified by the activation of different P2Y receptors subtypes, according to our pharmacological studies. It is clear that the pharmacology of $\mathrm{P} 2$ receptors is rather complicated due to the lack of selective antagonists. A possible picture of the receptors involved in the acceleration of re-epithelialization or its delay may be obtainable by studying the behavior of several purinergic agonists.

The increase in the rate of re-epithelialization has been observed when $\mathrm{Ap}_{4} \mathrm{~A}$, UTP, and ATP were applied. This profile matches quite well with that described by Lazarowski et al., ${ }^{25}$ in which $\mathrm{Ap}_{4} \mathrm{~A}$ and UTP are the best agonists on the cloned $\mathrm{P}_{2} \mathrm{Y}_{2}$ receptor. A similar $\mathrm{P}_{2} \mathrm{Y}_{2}$ profile has been previously described for corneal wound healing and tear secretion, but the limitations of using living animals did not permit us to obtain conclusive results for those compounds that delay reepithelialization. ${ }^{16}$ With corneal epithelial cells in culture, it was possible to detect some dinucleotides that clearly reduced the rate of healing. Together with the study of mononucleo-

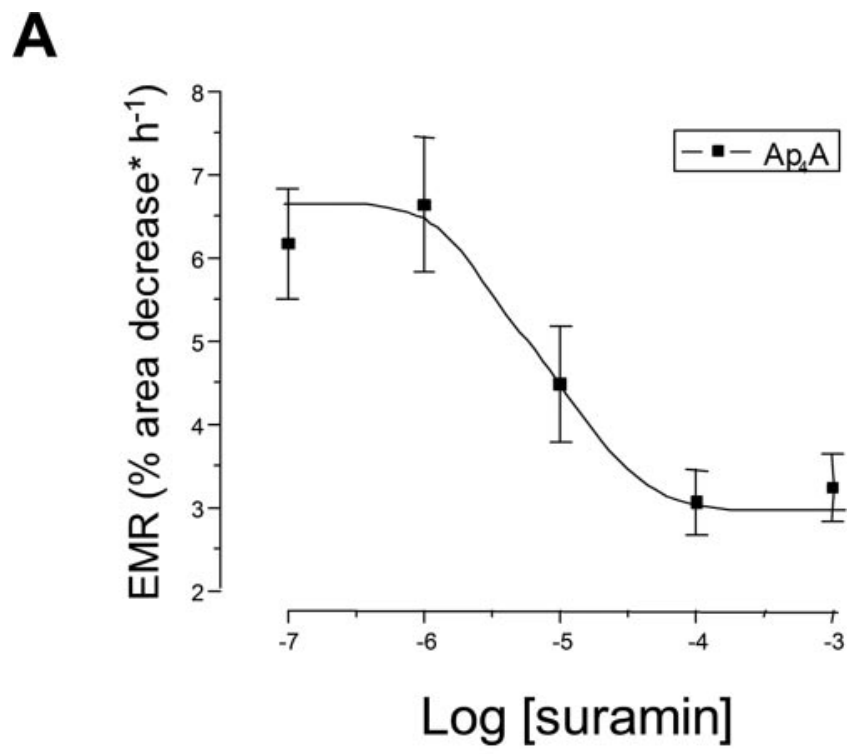

B

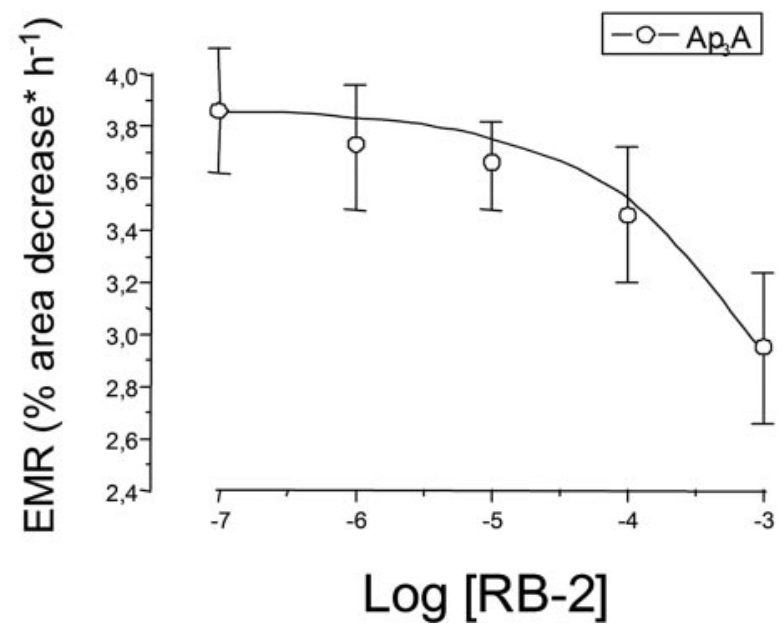

FIGURE 3. Concentration-response curves for the antagonists suramin and RB-2. (A) Concentration-response curve for the antago-

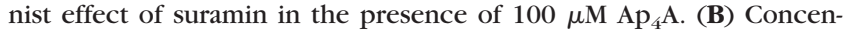
tration-response curve for the antagonist effect of RB-2 on $100 \mu \mathrm{M}$ $\mathrm{Ap}_{3} \mathrm{~A}$. 

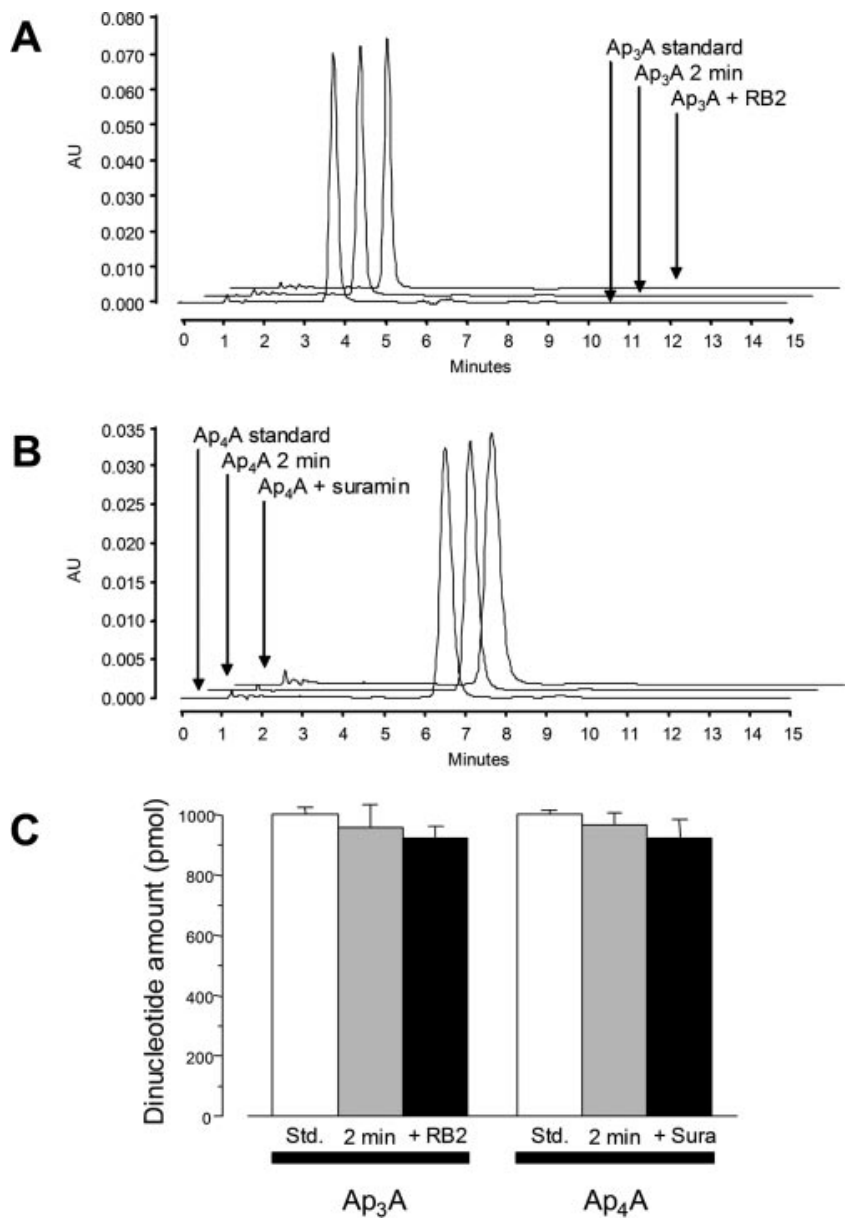

Figure 4. Stability of $\mathrm{Ap}_{3} \mathrm{~A}$ and $\mathrm{Ap}_{4} \mathrm{~A}$ on corneal epithelial cells in culture. (A) Diadenosine triphosphate stability was assayed as described in methods. $\mathrm{Ap}_{3} \mathrm{~A}$, either alone or in the presence of $\mathrm{RB}-2$, was only minimally degraded by the extracellular enzymes. (B) When the same experiments were performed for $\mathrm{Ap}_{4} \mathrm{~A}$, but with suramin as ectoenzyme inhibitor, minimal degradation was detected. (C) Column plot presenting the changes in the amount of $\mathrm{Ap}_{3} \mathrm{~A}$ and $\mathrm{Ap}_{4} \mathrm{~A}$ under the conditions described in (A) and (B).

tides it was possible to obtain a profile of those nucleotides that reduce the rate of re-epithelialization. A profile with the rank order of $A p_{5} A>A p_{3} A \cong U D P$ suggests the involvement of a $\mathrm{P}_{2} \mathrm{Y}_{6}$ receptor. This fact alters the idea of the $\mathrm{P}^{2} \mathrm{Y}_{6}$ receptor's being a pyrimidinoceptor, sensitive to UTP and UDP. Nevertheless, studies performed with diadenosine polyphosphates and $\mathrm{P} 2 \mathrm{Y}_{6}$ receptors, heterologously expressed in $1321 \mathrm{~N} 1$ cells, demonstrate that both $\mathrm{Ap}_{3} \mathrm{~A}$ and $\mathrm{Ap}_{5} \mathrm{~A}$ are agonists of the $\mathrm{P} 2 \mathrm{Y}_{6}$ receptor, although the concentration required for the receptor stimulation are higher than those of the best agonist, UDP. ${ }^{26}$ Also, recently the design of novel dinucleoside polyphosphates with uridine as the nucleoside moiety $\left(\mathrm{Up}_{\mathrm{n}} \mathrm{U}\right)$ has demonstrated that some of them are quite effective in activating the $\mathrm{P}^{2} \mathrm{Y}_{6}$ receptor. $^{27}$

The involvement of metabotropic $\mathrm{P} 2$ receptors in corneal wound healing has been reported by other groups. ${ }^{28-30}$ The presence of $\mathrm{P}_{2} \mathrm{Y}_{2}, \mathrm{P}_{2} \mathrm{Y}_{4}$, and $\mathrm{P} 2 \mathrm{Y}_{11}$, on corneal epithelial cells seems to be clear from a pharmacological point of view. Discussion arises when the presence of $\mathrm{P}_{2} \mathrm{Y}_{1}$ or $\mathrm{P}_{2} \mathrm{Y}_{6}$ is investigated. The assay of UDP, together with the enzyme hexokinase suggests the presence of a $\mathrm{P}_{2} \mathrm{Y}_{6}$ receptor in these cells. ${ }^{28}$
Concerning the second-messenger system underlying the activation of those receptors, it seems that both intracellular $\mathrm{Ca}^{2+}$ mobilization ${ }^{29-31}$ and MAP kinase cascade activation ${ }^{28}$ are involved. These intracellular mechanisms which accelerate the rate of healing, seems to be triggered by $\mathrm{P} 2 \mathrm{Y}_{2}$ and $\mathrm{P}_{2} \mathrm{Y}_{4}$ membrane receptors. ${ }^{30}$ These results match well with the effect of $\mathrm{Ap}_{4} \mathrm{~A}$, UTP, and ATP described in the present work, which indicates the activation of a $\mathrm{P}_{2} \mathrm{Y}_{2}$ receptor.

$\mathrm{Ap}_{4} \mathrm{~A}$ is effective inducing an increase in the rate of migration by stimulating a $\mathrm{P} 2 \mathrm{Y}_{2}$ receptor, whereas $\mathrm{Ap}_{3} \mathrm{~A}$ and $A \mathrm{p}_{5} \mathrm{~A}$ do the opposite by activating a $\mathrm{P}_{2} \mathrm{Y}_{6}$ receptor. This dual role of diadenosine polyphosphates may have a physiological meaning in the intact tissue. Corneal wound healing is a process that occurs in three main steps: lag phase, migration, and mitosis. ${ }^{31,32}$ It could be the case that in the intact corneal epithelium, $\mathrm{P} 2 \mathrm{Y}_{2}$ receptors would be the relevant ones facilitating the migration rate (termed phase 2 ) in intact corneas. It is necessary to take into consideration that in the model we use, the lag phase (phase 1) is reduced. This reduction is because the cells do not have to perform some of the pathophysiological processes that occur in the intact cornea after injury. In the whole cornea, polymorphonuclear leukocytes remove necrotic cells from the wound margin. Also, hemidesmosomal attachments between the basement membrane and the basal cells disappear. ${ }^{31,32}$ All these phenomena did not occur in our preparation, because it contained only a monolayer of epithelial cells.

On the other hand, $\mathrm{P}_{2} \mathrm{Y}_{6}$ would be critical in stopping migration and starting the third phase (mitosis). It is clear that we do not have any evidence for the role of $\mathrm{P}_{2} \mathrm{Y}_{6}$ receptor to confirm this idea, but it would not be strange to think that $\mathrm{P}_{2} \mathrm{Y}_{2}$ and $\mathrm{P}_{2} \mathrm{Y}_{6}$ are switches that control the transition from wound-healing phase 2 to phase 3 . More experiments will be necessary to confirm this hypothesis fully.

Preliminary experiments performed with living rabbits established that the topical application of certain nucleotides clearly reduce the time of corneal wound healing. ${ }^{16}$ At that moment, we were not able to indicate whether the nucleotides were activating epithelial cell $\mathrm{P} 2 \mathrm{Y}$ receptors or if the topical application of these substances were inducing tear secretion, and a component present in the tears was the responsible for the re-epithelialization. In the present work, it seems clear that the application of $\mathrm{Ap}_{4} \mathrm{~A}$ and other mononucleotides acts directly on the $\mathrm{P} 2 \mathrm{Y}$ receptors present in the rabbit corneal epithelial cells and that they are responsible for the woundhealing effect.

Diadenosine polyphosphates are present in rabbit tears. ${ }^{15}$ They therefore, may contribute to the modification of the rate of healing. Because the only two dinucleotides present in tears are $A p_{4} A$ and $A p_{5} A$ and considering that the first accelerates the rate of migration and the other produces just the opposite effect, we may observe an apparent no-effect. Nevertheless, a detailed study of the concentrations of both dinucleotides in the rabbit tears indicates that $\mathrm{Ap}_{4} \mathrm{~A}$ concentration is five times higher than that of $\mathrm{Ap}_{5} \mathrm{~A}$ ( $3 \mu \mathrm{M}$ for $\mathrm{Ap}_{4} \mathrm{~A}$ and $0.6 \mu \mathrm{M}$ for $\left.\mathrm{Ap}_{5} \mathrm{~A}\right)$. Taking these results together and according to our dose-response curves, the predominant effect would be the one triggered by $\mathrm{Ap}_{4} \mathrm{~A}$.

Another interesting question related to the previous one is whether the levels of both compounds vary after corneal injury. In vivo experiments performed in our laboratory demonstrated that the levels of $A p_{4} A$ and $A p_{5} A$ are significantly reduced after the injury but they recover after 10 hours (results not shown). Under the experimental conditions, although $A p_{4} A$ and $A p_{5} A$ concentrations were reduced, they kept the same proportion between the respective concentrations that occur in normal tears $\left(3 \mu \mathrm{M} \mathrm{Ap_{4 }} A\right.$ and $0.6 \mu \mathrm{M} \mathrm{Ap} \mathrm{p}_{5} \mathrm{~A}$, a ratio pf $5: 1)$. Furthermore, they remain low during the lag phase and 
recover during the migration phase, suggesting their involvement in the migration process. Further experiments are needed to see whether their levels and even their proportions change in the mitosis phase.

In summary, diadenosine polyphosphates have a dual role in corneal epithelial cells. On the one hand, $\mathrm{Ap}_{4} \mathrm{~A}$ can accelerate the rate of migration, whereas on the contrary, $A_{3} \mathrm{~A}$ and $\mathrm{Ap}_{5} \mathrm{~A}$ delay this process, probably starting others that remain unknown. More work is necessary to understand fully the cross-talk between these two actions and under what conditions one is superimposed on the other.

\section{Acknowledgments}

The authors thank Ben Yerxa (Inspire Pharmaceuticals, Inc., Durham, NC) for his help in the preparation of the manuscript.

\section{References}

1. Burnstock G, Knight GE. Cellular distribution and functions of P2 receptor subtypes in different systems. Int Rev Cytol. 2004;240: 301-304.

2. Burnstock $G$, Kennedy C. Is there a basis for distinguishing two types of P2-purinoceptor? Gen Pharmacol. 1985;16:433-440.

3. Sak K, Webb TE. A retrospective of recombinant P2Y receptor subtypes and their pharmacology. Arch Biochem Biopbys. 2002; 397:131-136.

4. Boeynaems JM, Communi D, Gonzalez NS, Robaye B. Overview of the P2 receptors. Semin Thromb Hemost. 2005;31:139-149.

5. Boeynaems JM, van Giezen H, Savi P, Herbert JM. P2Y receptor antagonists in thrombosis. Curr Opin Investig Drug. 2005;6:275282.

6. North RA. Molecular physiology of P2X receptors. Physiol Rev. 2002;82:1013-1067.

7. Vial C, Roberts JA, Evans RJ. Molecular properties of ATP-gated P2X receptor ion channels. Trends Pharmacol Sci 2004;25:487493.

8. Khakh BS. Molecular physiology of P2X receptors and ATP signalling at synapses. Nat Rev Neurosci. 2001;2:165-174.

9. Pintor J. Purinergic signalling in the eye. In: Burnstock G, Sillito AM, eds. Nervous Control of the Eye. Binghamton, NY: Harwood Academic Publishers; 2000:171-210.

10. Pintor J, Sanchez-Nogueiro J, Irazu M, Mediero A, Pelaez T, Peral A. Immunolocalisation of $\mathrm{P} 2 \mathrm{Y}$ receptors in the rat eye. Purinerg Signal. 2004;1:83-90.

11. Rodriguez del Castillo A, Torres M, Delicado EG, Miras-Portugal MT. Subcellular distribution studies of diadenosine polyphosphates $\mathrm{Ap}_{4} \mathrm{~A}$ and $\mathrm{Ap}_{5} \mathrm{~A}$ in bovine adrenal medulla: presence in chromaffin granules. J Neurochem. 1988;51:1696-1703.

12. Pintor J, Diaz-Hernandez M, Gualix J, Gomez-Villafuertes R, Hernando F, Miras-Portugal MT. Diadenosine polyphosphate receptors: from rat and guinea-pig brain to human nervous system. Pharmacol Ther. 2000;87:103-115.

13. Soto, D, Pintor J, Peral A, Gual A, Gasull X. Effects of dinucleoside polyphosphates on trabecular meshwork cells and aqueous humor outflow facility. J Pharmacol Exp Ther. 2005;314:1042-1051.

14. Pintor J, Carracedo G, Alonso MC, Bautista A, Peral A. Presence of diadenosine polyphosphates in human tears. Pflugers Arch. 2002; 443:432- 436
15. Pintor J, Peral A, Hoyle CH, et al. Effects of diadenosine polyphosphates on tear secretion in New Zealand white rabbits. J Pharmacol Exp Ther. 2002;300:291-297.

16. Pintor J, Bautista A, Carracedo G, Peral A. UTP and diadenosine tetraphosphate accelerate wound healing in the rabbit cornea. Opbthalmic Physiol Opt. 2004;24:186-193.

17. Gipson IK, Grill SM. A technique for obtaining sheets of intact rabbit corneal epithelium. Invest Opbthalmol Vis Sci. 1982;23: 269-273.

18. Shanley LJ, McCaig CD, Forrester JV, Zhao M. Insulin, not leptin, promotes in vitro cell migration to heal monolayer wounds in human corneal epithelium. Invest Opbthalmol Vis Sci. 2004;45: 1088-1094

19. Desai LP, Aryal AM, Ceacareanu B, Hassid A, Waters CM. RhoA and Rac1 are both required for efficient wound closure of airway epithelial cells. Am J Pbysiol 2005;287:1134-1144.

20. Crosson CE, Klyce SD, Beuerman RW. Epithelial wound closure in the rabbit cornea: a biphasic process. Invest Opbthalmol Vis Sci 1986;27:464-473

21. Valster A, Tran NL, Nakada M, Berens ME, Chan AY, Symons M. Cell migration and invasion assays. Methods. 2005;37:208-215.

22. Lee JG, Kay EP. FGF-2-induced wound healing in corneal endothelial cells requires Cdc42 activation and Rho inactivation through the phosphatidylinositol 3-kinase pathway. Invest Ophtbalmol Vis Sci. 2006; 47:1376-1386.

23. Schermer A, Galvin S, Sun TT. Differentiation-related expression of a major $64 \mathrm{~K}$ corneal keratin in vivo and in culture suggests limbal location of corneal epithelial stem cells. J Cell Biol 1986;103:49 62

24. Lazarowski ER, Homolya L, Boucher RC, Harden TK. Direct demonstration of mechanically induced release of cellular UTP and its implication for uridine nucleotide receptor activation. J Biol Chem 1997;272:24348-24354.

25. Lazarowski ER, Watt WC, Stutts MJ, Boucher RC, Harden TK. Pharmacological selectivity of the cloned human P2Upurinoceptor: potent activation by diadenosine tetraphosphate. Br J Pharmacol 1995;116:1619-1627.

26. Patel K, Barnes A, Camacho J, et al. Activity of diadenosine polyphosphates at $\mathrm{P} 2 \mathrm{Y}$ receptors stably expressed in $1321 \mathrm{~N} 1$ cells. Eur J Pharmacol. 2001;430:203-210.

27. Pendergast W, Yerxa BR, Douglass JG 3rd, et al. Synthesis and P2Y receptor activity of a series of uridine dinucleoside $5^{\prime}$-polyphosphates. Bioorg Med Chem Lett. 2001;11:157-160.

28. Yang L, Crason D, Trinkaus-Randall V. Cellular injury induces activation of MAPK via P2Y receptors. J Cell Biochem. 2004;91: 938-950.

29. Klepeis VE, Weinger I, Kaczmarek E, Trinkaus-Randall V. P2Y receptors play a critical role in epithelial cell communication and migration. J Cell Biochem. 2004;93:1115-1133.

30. Weinger I, Klepeis VE, Trinkaus-Randall V. Tri-nucleotide receptors play a critical role in epithelial cell wound repair. Purinerg Signal. 2005;1:281-292.

31. Suzuki K, Saito J, Yanai R, et al. Cell-matrix and cell-cell interactions during corneal epithelial wound healing. Prog Retin Eye Res. 2003;22:113-133.

32. Steele C. Corneal wound healing: a review. Optometry Today. 1999;24:28-32. 